\title{
BEHAVIOURAL ANALYSIS OF MICROGRID: A SUBSET OF SMART GRID
}

\author{
Dharshini G' ${ }^{1}$, Ramya J Rao ${ }^{2}$, Sangeeta Modi ${ }^{3}$ \\ ${ }^{1}$ Department of Electrical and Electronics PES University, Bangalore, India \\ ${ }^{2}$ Department of Electrical and Electronics PES University, Bangalore, India \\ ${ }^{3}$ Department of Electrical and Electronics PES University, Bangalore, India
}

\begin{abstract}
Microgrid is a integration of distributed energy resources which can be tied to the utility grid through power electronic interface. The proposed system can be employed for rural electrification. In this paper active $(P)$ and reactive $(Q)$ power control is implemented for AC microgrid system in grid-connected mode. The power electronic interface used in the sytem is the multilevel inverter. The sources are coupled through three level inverter and connected to the utility grid. The selected microgrid configuration includes a $24 \mathrm{~kW}$ of photovoltaic cell module, $20 \mathrm{~kW}$ of PMSG based wind turbine module, fuel cell stack of $9.6 \mathrm{~kW}$. The PQ control strategy is applied to the three level inverter to maintain the system voltage and frequency. A phase locked loop is employed in the control strategy to synchronize utility grid and the microsources. The decoupled current $\left(I_{d} \& I_{q}\right)$ is used to control active and reactive power through $P Q$ control algorithm and it is applied to inverter. Active and reactive power is controlled using $I_{d}$ and $I_{q}$ respectively. The control strategy is simulated in MATLAB/Simulink.
\end{abstract}

Keywords-Microgrid, Distributed Energy Sources, Control of Microgrid, Grid-Connected Mode, Inverter Control

\section{INTRODUCTION}

The microgrid(MG) is energy system consisting of distributed energy sources, it is solution to the increasing energy demand and the alternative to the existing conventional grids. It can operate independently and even it can be connected to the utility grid. It reduces the green house effect using renewable energy sources. A small scale microgrid behaves as a basic system for future smart grids. Introducing microsources(MCs) to the grid will provide continuous power flow to the consumers.

The decentralized and centralized are the controls applied to microgrid. In centralized approach, the sources are controlled from a central master controller and this operates with large bandwidth for the control. In decentralized approach, the individual sources are controlled with individual local controller as per the capability of distributed energy sources for power flow[1], [2].

The inverter control strategy used in this system implements the $\mathrm{P}$ and $\mathrm{Q}$ control using decoupled currents. The MG voltage and frequency should be properly matched with main grid frequency and voltage in grid connected mode. [3][8].

The microgrid has PV, wind and diesel system.[4] The PV system is modeled with a DC/AC inverter with a MPPT for tracking maximum power and fixed turbine induction generator based wind turbine is used. This system studies the intermittent operation of microgrid between the sources.
The hybrid system in islanded mode of operation with PV, wind turbine and fuel stack is reported in [5]. In this system inverter output is connected to a RLC load for the power analysis with constant DC link voltage.

\section{SYSTEM DISCRIPTION}

The schematic diagram of a AC microgrid system under study is as shown in the Fig.1. The distributed energy sources used are photovoltaic panel, wind turbine and fuel stack. All the microsources are connected to the common DC link and through inverter it is integrated to the grid

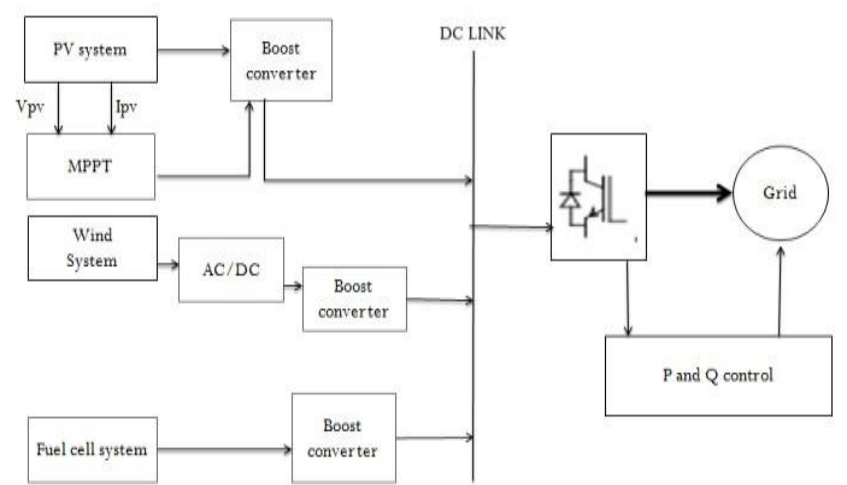

Fig.1. Schematic diagram of hybrid system

\subsection{Photovoltaic System}

The PV system is designed to generate power of $24 \mathrm{~kW}$ of rated power regarding 25 degree Celsius and irradiation of $1000 \mathrm{~W} / \mathrm{m}^{2}$. The irradiation is oscillated between $250 \mathrm{~W} / \mathrm{m}^{2}$ and $1000 \mathrm{~W} / \mathrm{m}^{2}$, to track this irradiation at 
maximum power point(MPP) the tracking algorithm is needed. Incremental conductance is the MPPT technique used in this system. The MPPT is used to reduce the oscillations in power and losses, and it is done by dc-dc boost converter by adjusting the duty cycle. Table 1 gives the parameters for the PV cell which can be changed as per the commercial PV value.[4]

$\mathrm{I}=\mathrm{I}_{\mathrm{Sat}}\left[\exp \left(\mathrm{V}_{\mathrm{d}} / \mathrm{V}_{\mathrm{T}}\right)\right]$

$\mathrm{I}=$ Diode current $(\mathrm{A})$

$\mathrm{I}_{\text {sat }}=$ Saturation current of diode. $(\mathrm{A})$

$\mathrm{V}_{\mathrm{d}}=$ Diode voltage $(\mathrm{V})$

$\mathrm{V}_{\mathrm{T}}=$ Temperature voltage

$\mathrm{VT}_{\mathrm{T}}=(\mathrm{k} \cdot \mathrm{T}) /$ (q.Qf. $\left.\mathrm{N}_{\bmod } \cdot \mathrm{N}_{\mathrm{str}}\right)$

$\mathrm{T}=$ cell temperature $(\mathrm{K})$

$\mathrm{k}=$ Boltzman constant $=1.3806 \mathrm{~J} . \mathrm{K}^{\wedge}-1$

$\mathrm{q}=$ Electron charge $=1.6022 \mathrm{e}-19 \mathrm{C}$

$\mathrm{Qf}=$ Diode quality factor

$\mathrm{N}_{\text {mod }}=$ Number of series connected cells per module

$\mathrm{N}_{\text {str }}=$ Number of series connected modules per string

\subsection{Wind Turbine System}

The PMSG based wind turbine is used, it is a variable speed wind turbine. The variable speed turbine is more efficient than fixed speed wind turbine. An uncontrolled diode bridge rectifier is used between the wind generator terminals and the input of boost converter. The wind module is connected to the common DC link. Table 1 gives the parameters of wind system.

The mechanical power $(\mathrm{P})$ delivered by wind turbine can be expressed as in (3)

$$
\mathrm{P}=\mathrm{C}_{\mathrm{p}}\left(\lambda_{\mathrm{W}}, \beta_{\mathrm{W}}\right) \rho \mathrm{A}_{\mathrm{W}} \mathrm{v}^{3}{ }_{\mathrm{W}} / 2
$$

Where power coefficient of the turbine is $\mathrm{C}_{\mathrm{p}}, \rho$ is the air density $(\mathrm{kg} / \mathrm{m} 3), \mathrm{A}_{\mathrm{W}}$ is turbine swept area $\left(\mathrm{m}^{2}\right), v_{\mathrm{W}}$ is wind speed $(\mathrm{m} / \mathrm{s}), \beta_{\mathrm{W}}$ is blade pitch angle (degree) and $\lambda_{\mathrm{W}}$ is tip speed ratio given by (3). [4]

$$
\lambda_{\mathrm{W}}=\omega_{\mathrm{r}} \mathrm{R} / \mathrm{v}_{\mathrm{W}}
$$

\subsection{Fuel Stack}

The fuel cell employed in the system is alkaline fuel cell (AFC) and preset model is available in simulink is used. The electrochemical reactions are used to convert chemical energy of fuel cell to electrical. The Table 1 gives the design parameters of fuel cell.

$$
\begin{gathered}
\mathrm{O}_{2}+2 \mathrm{H}_{2} \mathrm{O}+4 \mathrm{e}^{-} \rightarrow 4 \mathrm{OH}^{-} \\
\mathrm{O}_{2}+2 \mathrm{H}_{2} \mathrm{O}+2 \mathrm{e}^{-} \rightarrow \mathrm{HO}^{-}+\mathrm{OH}^{-} \\
\mathrm{HO}^{-}+\mathrm{H} \mathrm{O}+2 \mathrm{e}^{-} \rightarrow 3 \mathrm{OH}^{-}
\end{gathered}
$$

\begin{tabular}{|c|c|}
\hline \multicolumn{2}{|l|}{ Solar energy plant } \\
\hline Rated power of each panel & $305.6 \mathrm{~W}$ \\
\hline Open circuit voltage $\left(\mathrm{V}_{\mathrm{Oc}}\right)$ & $64.2 \mathrm{~V}$ \\
\hline Maximum power voltage & $54.7 \mathrm{~V}$ \\
\hline Short circuit current $\left(\mathrm{I}_{\mathrm{Sc}}\right)$ & $5.96 \mathrm{~A}$ \\
\hline Maximum power current & $5.58 \mathrm{~A}$ \\
\hline Series panel in each array & 5 \\
\hline Number of parallel array & 16 \\
\hline \multicolumn{2}{|l|}{ Wind energy plant } \\
\hline Generator type & PMSG \\
\hline Nominal voltage & $960 \mathrm{~V}$ \\
\hline Rated power & $20 \mathrm{~kW}$ \\
\hline Maximum power & $20 \mathrm{~kW}$ \\
\hline Rated speed & $12 \mathrm{~m} / \mathrm{s}$ \\
\hline Stator phase resistance & $0.0485 \Omega$ \\
\hline Torque & $1800 \mathrm{Nm}$ \\
\hline \multicolumn{2}{|l|}{ Fuel Cell Energy Plant } \\
\hline Number of Cell & 68 \\
\hline Maximum Current & 50 \\
\hline Vnom at Max. operating point & 48 \\
\hline Nominal stack efficiency (\%) & 58 \\
\hline $\begin{array}{l}\text { Nominal supply pressure } \\
\text { [Fuel (bar), Air (bar)] }\end{array}$ & {$\left[\begin{array}{ll}6 & 1\end{array}\right]$} \\
\hline Nominal Air flow rate (lpm) & 300 \\
\hline
\end{tabular}

Table 1: Design parameters of AC microgrid system

\subsection{Multilevel Invereter}

Inverter is the power electronic device for the conversion of DC signal to AC signal. The multilevel inverter is used as an alternative to the high power and medium voltage. It is easily used in renewable energy sources for interfacing to the utility grid as it is high power applications. The main advantage of using multilevel inverter is to reduce harmonics. Through common DC link inverter is interfaces distributed energy sources to the utility grid.

\section{CONTROL STRATEGY}

The microgrid implemented uses centralized control, it uses an control strategy for controlling $\mathrm{P}$ and Q. This control 2 is applicable only when distributed energy resources are integrated to the utility grid. The reference will be considered from utility grid voltage and frequency. [7][8]

The basic principle of PQ inverter control strategy is to control active and reactive power instantaneously and independent of each other. Fig 2 shows the P and Q control 
scheme for inverter. This control principle operates in $\mathrm{dq}$ reference frame and hence obtained three phase voltage is converted from abc to dq reference frame through Park's transformation. The PLL technique is employed to detect the phase angle of grid voltage to synchronize the delivered power. The input to PLL is three phase grid voltage and current and tracked phase angle is the output from PLL. The phase angle is tracked using the PI regulator.

The outer control loop controls the current from measured DC link $\left(\mathrm{V}_{\mathrm{dc}}\right)$ and the reference $\mathrm{V}^{*} \mathrm{dc}$. Active power flow or $\mathrm{dc}$ voltage level is controlled with $\mathrm{I}_{\mathrm{d}}$. Similarly, reactive power is controlled with $\mathrm{I}_{\mathrm{q}}$ under grid connection.

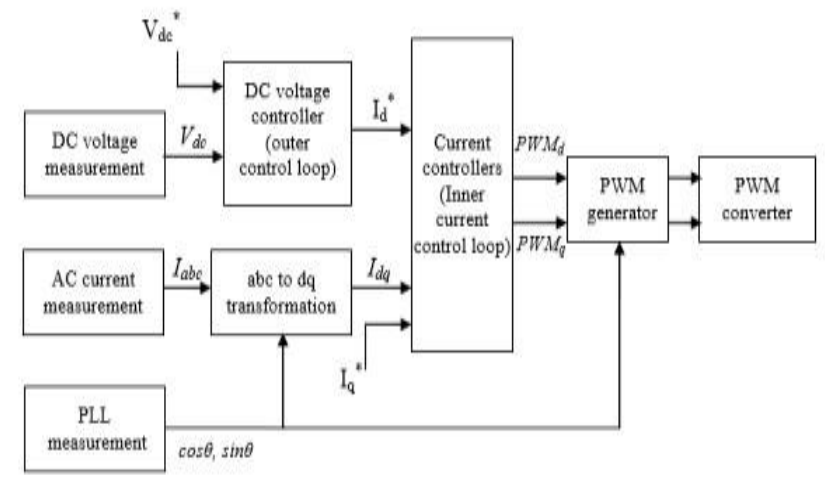

The inner current control loop takes the error between the reference current and measured current as input. The PI regulator is used to rgulate the error and the decoupling terms. The desired converter voltage is obtained in $\mathrm{dq}$ reference frame. This is given as control to inverter through pulse generator. [7][8] The equation 8 shows the power calculation in dq reference frame.

$$
\begin{gathered}
P=v_{d} i_{d}+v_{q} i_{q} \\
Q=v_{q} i_{d}+v_{d} i_{q}
\end{gathered}
$$

\section{SIMULATION RESULT}

The selected AC Microgid test bed is simulated as in fig 3 and performed to analyze the generated power from each microsources. The below fig 4 shows the output power from each renewable energy sources. Fig 4a shows the power generated from the PV source to the variations in irradiation. The PV source is applied with MPPT (Incremental conductance) to tack the maximum power for different irradiation. $24 \mathrm{~kW}$ is the power generated from PV. Fig $4 \mathrm{~b}$ shows the output power of wind for $12 \mathrm{~m} / \mathrm{s}$ wind speed. $14 \mathrm{~kW}$ is the power from wind. Fig $4 \mathrm{c}$ gives the power output from fuel stack. $8 \mathrm{~kW}$ is the power from fuel.

Fig 2. PQ control strategy

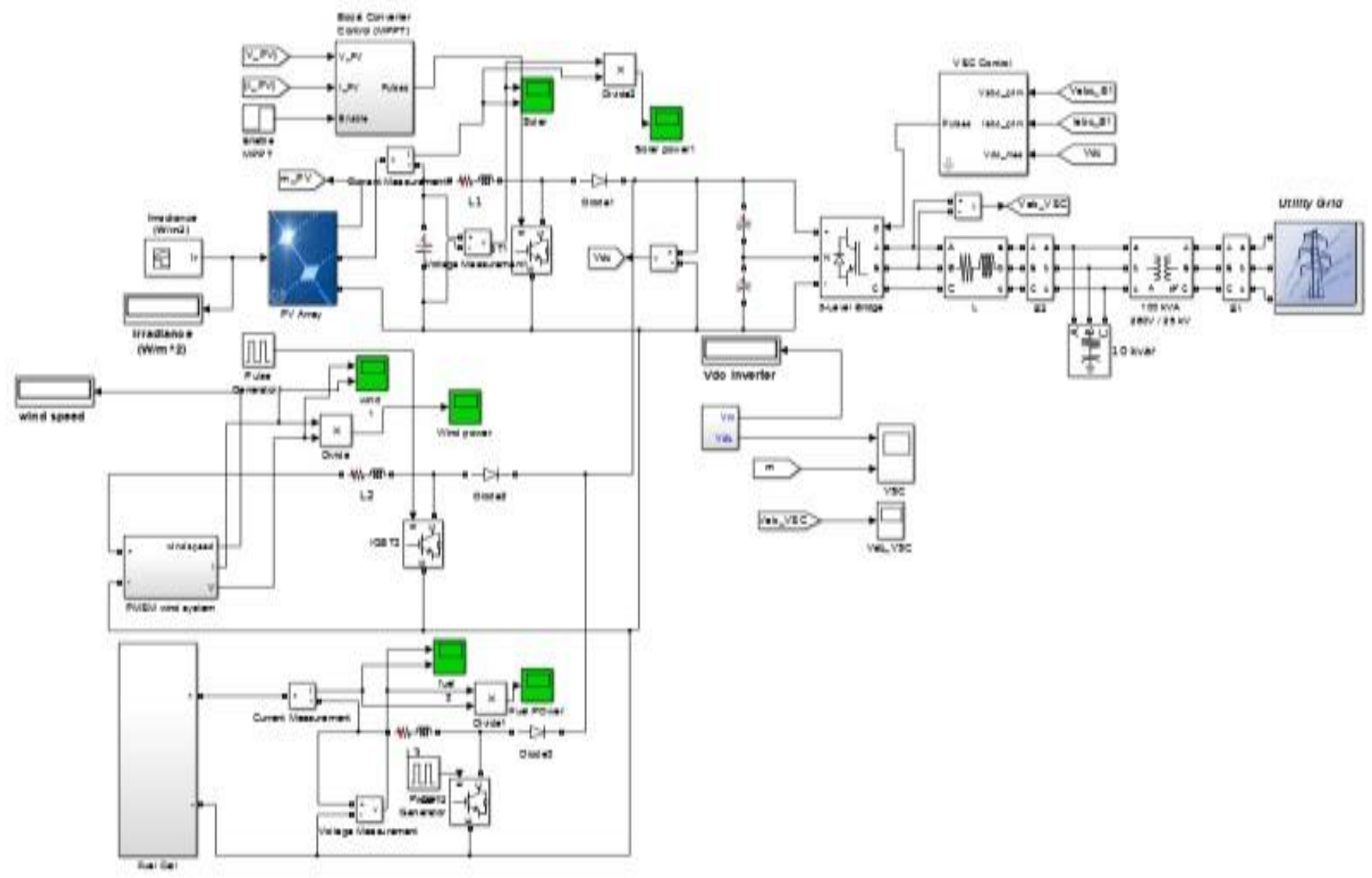

Fig 3. Simulation circuit 


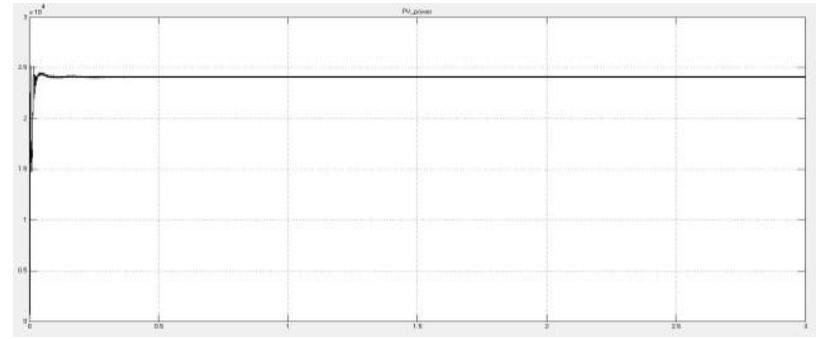

(a)

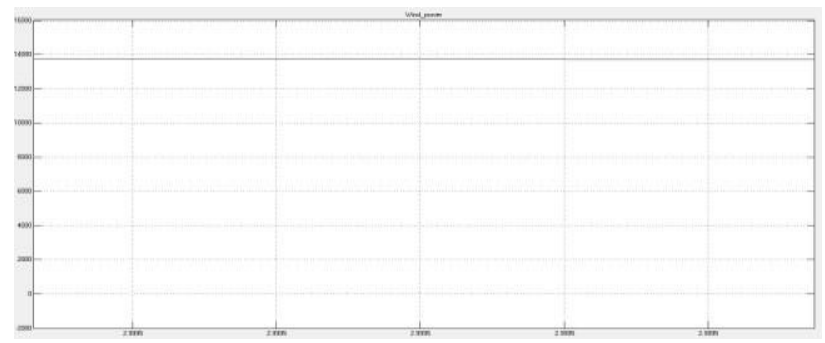

(b)

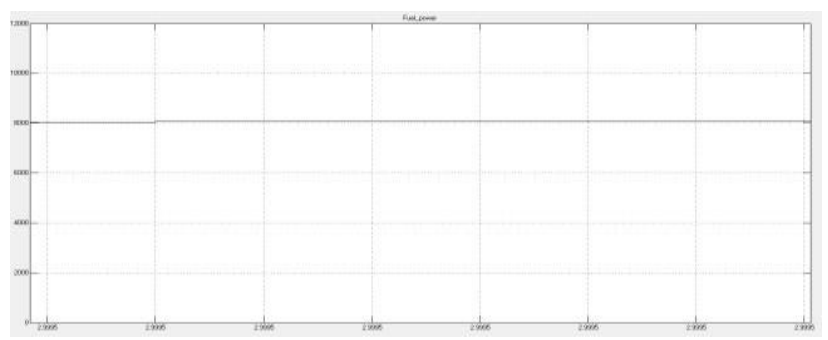

(c)

Fig 4. power generated from (a) PV source (b) Wind source (c) Fuel stack.

The microsources integrated together through a common DC link and an inverter interfaces the distributed energy sources to the utility grid. The $500 \mathrm{~V}$ is maintained at DC link voltage and fig 5 gives the output of a inverter.

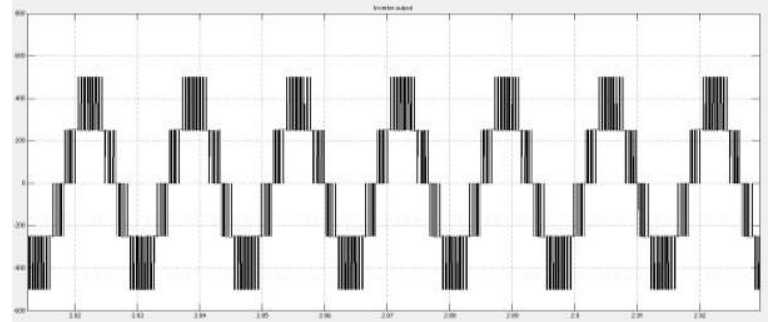

Fig 5. Inverter output waveform.

\subsection{Case 1: Grid Connected Mode}

The microsources and the uitilty grid supplies the load. The DC link is maintained constant by VSC control by tuning the PI regulators, and the control algorithm uses PLL to maintain the system voltage and frequency. In this case the load is set for $60 \mathrm{~kW}$ and 100 var. The total capacity of the microsources are $46 \mathrm{~kW}$. The microgrid local sources are supplying $44.8 \mathrm{~kW}$ of real power. The below fig 6 shows load voltage and current, active and reactive power across load. The remaining $15 \mathrm{~kW}$ and 100var of power to the load is supplied from utility grid as shown below. The fig 7 shows the voltage, current, active and reactive power across the grid. This also indicates that the PLL implemented in Simulink is operating successfully in synchronizing the microgrid with the utility grid.

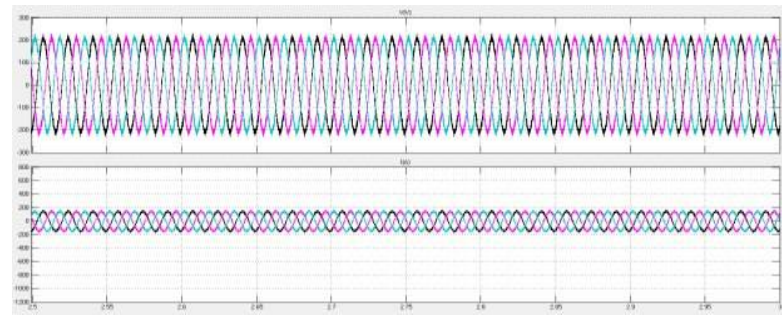

(a)

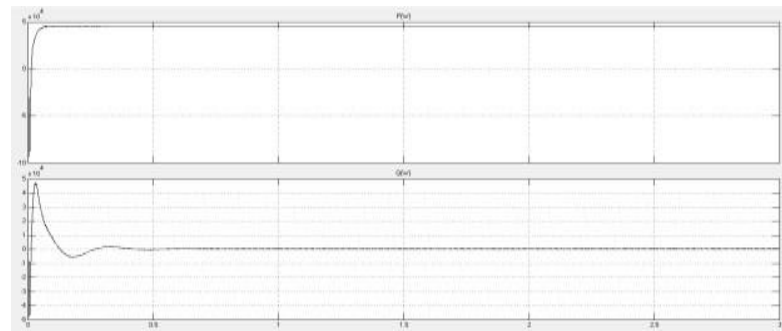

(b)

Fig 6. (a) load voltage and load current, (b)Active and reactive power delivered from sources.

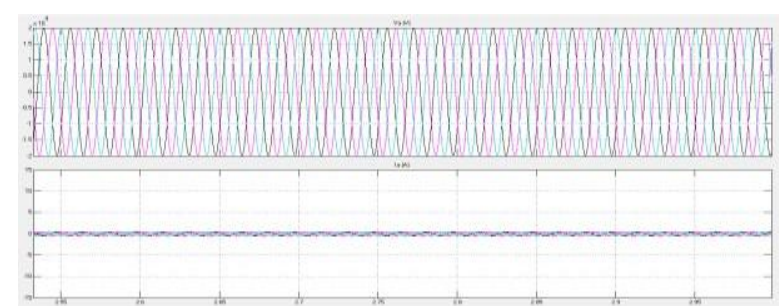

(a)

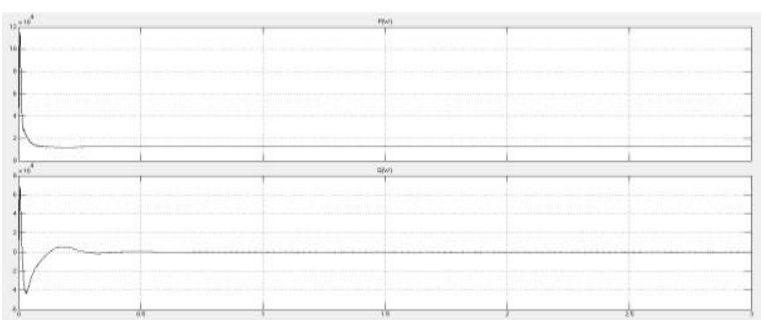

(b)

Fig 7. (a) grid voltage and grid current, (b) power delivered from grid.

\subsection{Case 2: Transition from Islanded to Grid Connected Mode}

When the system is operating normally the circuit breaker is closed and the sources are operating at rated voltage. When there is any disturbance in the system, the breaker is open. In this case, at start microsources will supply power to the load normally until $1.5 \mathrm{~s}$, at $1.501 \mathrm{~s}$ theirs a disturbance in the system at the breaker is open. Then after $1.501 \mathrm{~s}$ utility grid supplies power to the load. The total capacity of the load is 
50kW. Fig 8 shows the power delivered to the load from microsources, voltage and current waveform. In fig $8 \mathrm{a}$, the voltage waveform shows that until $1.5 \mathrm{~s}$ the sources are suppling power and after $1.501 \mathrm{~s}$ theirs is a dip in voltage. The transient is because of sudden switching of breaker, and microsources supply $45 \mathrm{~kW}$ of power. Fig 9 shows the voltage, current and power delivered to the load from grid. In fig $9 \mathrm{a}$ upto $1.5 \mathrm{~s}$ the current is zero and there is a increase in voltage. In fig $9 \mathrm{~b}$ the power deliverd to the load of $5 \mathrm{~kW}$ is shown after $1.5 \mathrm{sec}$.

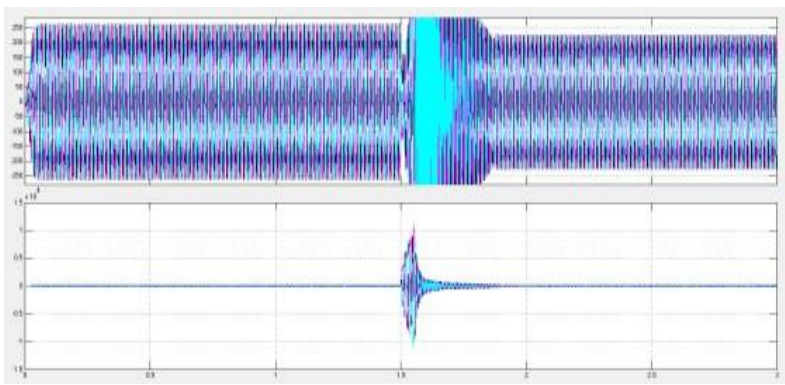

(a)

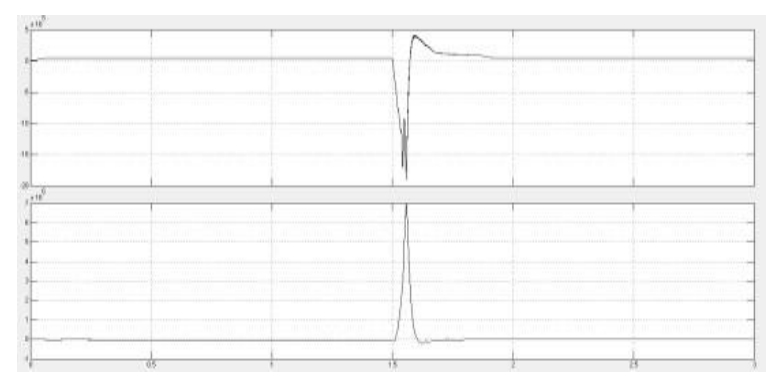

(b)

Fig 8. (a) voltage and current waveform, (b)Active and reactive power delivered from sources.

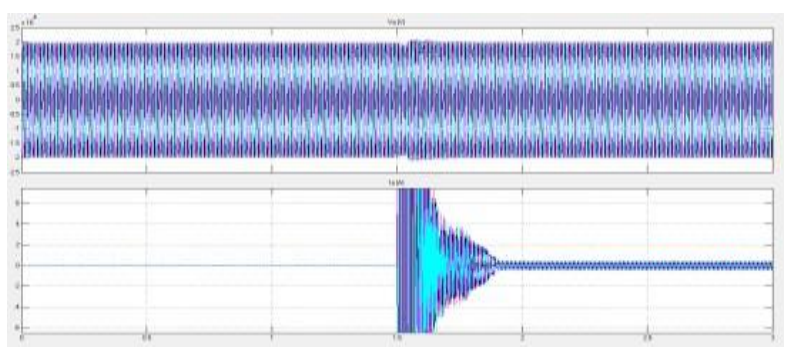

(a)

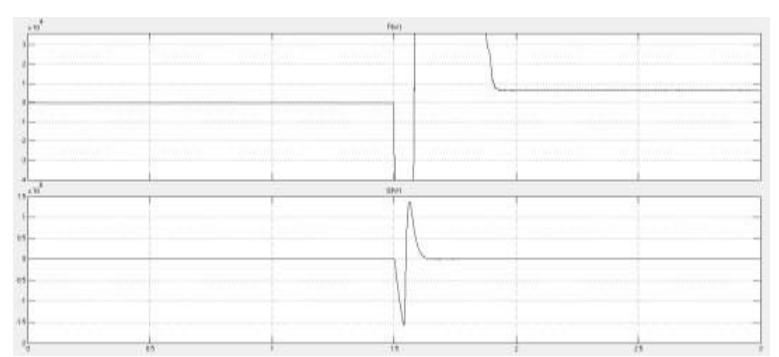

(b)

Fig 9. (a) grid voltage and grid current, (b)Active and reactive power delivered from grid.

\section{CONCLUSION}

In this paper control strategy for inverter has been implemented to maintain the system voltage and frequency, when microgrid is operating under grid connected mode. The selected AC microgrid consisting of wind module, PV module and fuel cell stack is simulated using MATLAB simulink environment. The simulation results shows that all the DER are sharing power as per their capacity. The power flow is continuous to the load even during the transition from islanded to grid connected mode. The switching transient appeared during transistion from islanded to grid connected mode has to be improved.

\section{REFERENCES}

[1]. Hartono B S, Budiyanto, Rudy Setiabudy, "Review of Microgrid Technology", 2013 IEEE.

[2]. Robert H Lasseter, Paolo Paigi, “ Microgrid: A Conceptual solution", $200435^{\text {th }}$ Annual IEEE Power electronics Specialists Conference.

[3]. Ramon Zamora, Anurag K. Srivastava, "Controls for microgrids with storage: Review, challenges, and research needs", Renewable and Sustainable Energy Reviews, Volume 14, Issue 7, pp. 2009-2018 September 2010.

[4]. Ersan Kabalci, Eklas Hossain, Ramazan Bayindir, "Microgrid Test-bed Design with Renewable Energy Sources", 2014 IEEE.

[5]. Mohammad S. Alotibe, Ruwan Chandrasena, and Sumedha Rajakaruna, "Simplified Voltage and Frequency Controller Based on Droop Control for the Dynamic Analysis of a Microgrid", IEEE.

[6]. Liping Su, Guojie Li, Zhijian Jin, "Modeling, Control and Testing of a Voltage-Source-Inverter-Based Microgrid", 2011 IEEE.

[7]. Yang chen, Jinbin Zhao, Jinlong Wang, Keqing Qu, Shuuichi Ushiki, Masaaki Ohshima, "A Decoupled PQ Control Strategy of Voltage Controlled Inverters", 2015 9th International Conference on Power Electronics-ECCE Asia. [8]. G. W. Chang, G. H. Zeng, H. J. Su, L. Y. Hsu, Y. R. Chang, Y. D. Lee, "Modelling and Simulation of INER AC Microgrid Control”, 2014 IEEE. 